\title{
Blockage of angiotensin II type I receptor decreases the synthesis of growth factors and induces apoptosis in C6 cultured cells and C6 rat glioma
}

\author{
O Arrieta*,', P Guevara', E Escobar', R García-Navarrete', B Pineda' and J Sotelo' \\ 'Neuroimmunology Unit of the National Institute of Neurology and Neurosurgery of Mexico, Insurgentes Sur 3877, 14269 Mexico City, Mexico
}

\begin{abstract}
Angiotensin II (Ang II) is a main effector peptide in the renin-angiotensin system and participates in the regulation of vascular tone. It also has a role in the expression of growth factors that induce neovascularisation which is closely associated to the growth of malignant gliomas. We have shown that the selective blockage of the AT, receptor of angiotensin inhibites tumour growth, cell proliferation and angiogenesis of $\mathrm{C} 6$ rat glioma. The aim of this study was to study the effects of the blockage of AT, receptor on the synthesis of growth factors, and in the genesis of apoptosis in cultured C6 glioma cells and in rats with C6 glioma. Administration of losartan at doses of 40 or $80 \mathrm{mg} \mathrm{kg}^{-1}$ to rats with C6 glioma significantly decreased tumoral volume and production of plateletderived growth factor, vascular endothelial growth factor and basic fibroblast growth factor. It also induced apoptosis in a dosedependent manner. Administration of Ang II increased cell proliferation of cultured C6 cells which decreased by the administration of losartan. Our results suggest that the selective blockage of AT, diminishes tumoral growth through inhibition of growth factors and promotion of apoptosis.

British Journal of Cancer (2005) 92, I247-1252. doi: I 0. 1038/sj.bjc.6602483 www.bjcancer.com

Published online 22 March 2005

(c) 2005 Cancer Research UK
\end{abstract}

Keywords: angiotensin; $A T_{1}$; glioblastoma; apoptosis; growth factors

The renin angiotensin aldosterone system (RAAS) has an important role in the regulation of blood pressure and fluid electrolyte balance. Angiotensin II (Ang II), a major participant in the RAAS, was initially described as a vasoconstrictor, but recent studies have revealed that it also participates in cell growth, cell differentiation and apoptosis (Stoll et al, 1995; Escobar et al, 2004), and has a role in cell migration and conformation of the extracellular matrix (Coker et al, 2001). Some reports indicate that Ang II induce neovascularisation (Fernandez et al, 1985; Le Noble et al, 1991; Andrade et al, 1996) due to stimulation of growth factors, such as platelet-derived growth factor (PDGF) (Khachigian et al, 2000; Cook et al, 2002), transforming growth factor beta $\beta$ (TGF $\beta$ ) (Kagami et al, 1994; Ohta et al, 1994; Hamaguchi et al, 1999; Weigert et al, 2002), insulin-like growth factor 1 (IGF-1) (Brink et al, 1999; Haddad et al, 2003), basic fibroblast growth factor (bFGF) (Peng et al, 2001), vascular endothelial growth factor (VEGF) (Otani et al, 1998; Tamarat et al, 2002) and angiopoietin 2 (Otani et al, 2001). Angiotensin II also induces the expression of proto-oncogenes in smooth vascular muscle cells, including $c$-fos, $c$-jun, $c-m y c$, erg-1,VL-30, and the activator of the protein 1 complex (Cook et al, 2002), Interestingly, many of these effects are inhibited by the blockage of the $\mathrm{AT}_{1}$ receptor (Fujiyama et al, 2001). Angiotensin II has a dual and paradoxical intervention in

*Correspondence: Dr O Arrieta; E-mail: ogar@servidor.unam.mx Revised 5 January 2005; accepted I February 2005; published online 22 March 2005 apoptosis through its receptors $\mathrm{AT}_{1}$ functioning as antiapoptotic and $\mathrm{AT}_{2}$ functioning as proapoptotic (Stoll et al, 1995).

Experimentally, the RAAS has been associated to proliferation of tumours; Ang II receptors have been found on the cell surface and cytoplasm of human tumours such as breast cancer (Guerra et al, 1993; Inwang et al, 1997; Berry et al, 2000; Muscella et al, 2002), hepatic carcinoma (Yoshiji et al, 2002), renal carcinoma (Hii et al, 1998; Miyajima et al, 2002), melanoma (Egami et al, 2003), colorectal carcinoma, squamous cell carcinoma (Takeda and Kondo, 2001), pancreas cancer (Fujimoto et al, 2001) and sarcomas (Volpert et al, 1996; Fujita et al, 2002).

Glioma is the most frequent primary tumour of the brain. Malignant gliomas are still associated with poor prognosis, the mean survival time of patients with glioblastoma multiforme (GBM) is 1 year, and it has not changed significantly for the last three decades (Lopez-Gonzalez and Sotelo, 2000). Glioblastoma multiforme is accompanied by extensive angiogenesis which is essential for tumoral growth and invasiveness; it also produces a vast amount of growth factors such as PDGF, VEGF, HGF and FGF (Strugar et al, 1995; Arrieta et al, 1998, 2002; Moriyama et al, 1999; Schmidt et al, 1999). In brain parenchyma there is a local RAAS, some neurons, glial cells and glioma cells express renin, angiotensinogen and receptors for Ang II ( $\mathrm{AT}_{1}$ and $\mathrm{AT}_{2}$ ) (Ganong, 1984, Ariza et al, 1988; Fogarty et al, 2002; Juillerat-Jeanneret et al, 2004). We have previously shown that the blockage of $\mathrm{AT}_{1}$ receptors in rats with $\mathrm{C} 6$ glioma inhibited tumour growth, cell proliferation and angiogenesis (Rivera et al, 2001). The aim of this 
study was to determine in vitro (in cultured C6 glioma cells) and in vivo (in rats with $\mathrm{C} 6$ glioma) the effects of the blockage of the $\mathrm{AT}_{1}$ receptor on the synthesis of growth factors and its relation with cell proliferation and apoptosis.

\section{MATERIALS AND METHODS}

\section{Glioma induction}

C6 glioma cells (American Tissue Culture Collection Rockville, $\mathrm{MD}$, USA) were cultured under sterile conditions at $37^{\circ} \mathrm{C}$ in a humid environment with $5 \% \mathrm{CO}_{2}$ in Dulbecco's modified Eagle's medium (DME) (Sigma chemical company, Saint Louis Missouri, USA) supplemented with $10 \%$ foetal bovine serum (GIBCO, New York, USA). After the cultures became confluent, the cells were washed with saline solution and harvested; $10^{7} \mathrm{C} 6$ cells from this source were inoculated intraperitoneally in a male Wistar rat; 2 weeks later, a large tumour was obtained (Guevara and Sotelo, 1999), it was mechanically dispersed in saline solution $(1: 1)$ at $4^{\circ} \mathrm{C}, 10^{7}$ cells from this source were subcutaneously injected in the left thigh of 40-day-old Wistar rats (Arrieta et al, 2001). All animals developed a noticeable tumour within 2 weeks. All animals used in this study were handled in accordance to the guidelines of the coordinating committee on cancer research for the welfare of animals with experimental neoplasms.

\section{Blockage of $\mathrm{AT}_{1}$ in vivo}

When the tumour had reached a diameter of $1.5 \mathrm{~cm}$, the rats were randomly assigned either to the control group $(n=40)$, to the losartan $40 \mathrm{mg} \mathrm{Kg}^{-1}$ group (L40) $(n=40)$, or to the losartan $80 \mathrm{mg} \mathrm{Kg}^{-1}$ group (L80) $(n=40)$. Losartan (Merck-Sharp \& Dohme, Mexico) was given orally, once a day, for 30 days. At the end of the experiment, 20 rats from each group were anaesthetised and perfused by intracardiac route with $10 \%$ formalin in saline solution for histological study. Before perfusion, the animals were bled by intracardiac puncture to analyse haematological and chemical parameters in blood; the body weight of animals from all groups remained similar throughout the study. The tumour was dissected and its volume was determined by water displacement. The tumours from nonperfused animals were kept at $-70^{\circ} \mathrm{C}$ until analysis.

\section{Histological analysis and apoptosis in vivo}

For microscopic study, the tumour was embedded in paraffin: $5 \mu \mathrm{m}$ sections were stained with haematoxylin and eosin. Apoptosis was detected by DNA fragmentation using TdT incorporation of nucleotides on $3^{\prime}$ ends of DNA (TUNEL technique). Briefly, $5 \mu \mathrm{m}$ of glioma $\mathrm{C} 6$ tumour sections was dewaxed and immersed in $3 \% \mathrm{H}_{2} \mathrm{O}_{2}$ to block endogenous peroxidase; after washing with distilled water, proteinase $\mathrm{K}$ $\left(20 \mu \mathrm{g} \mathrm{ml}^{-1}\right)$ was applied to the specimens for $15 \mathrm{~min}$ at room temperature. Detection of apoptosis in situ was made by ApopTag Peroxidase (Oncor, Gaithersburg, MD, USA) that detects fragmented DNA and was performed according to the manufactureŕs conditions. Sections were counterstained with methyl-green. Positive control sections were prepared by nicking DNA with DNase and negative control sections were prepared by substituting with distilled water for working strength TdT enzyme. The proportion of apoptotic cells was expressed as apoptotic rate, which represented the number of apoptotic cells among 1000 glioma C6 nucleated cells, excluding segmented neutrophils due to their short lifespan.

\section{Determination of growth factors in vivo}

In all, 10 samples from each experimental group were unfrozen, weighted, and homogenised at $4^{\circ} \mathrm{C}(1: 1)$ in saline solution;
$70 \mu \mathrm{g} \mathrm{ml}^{-1}$ of phenylmethylsulphonyl fluoride (PMSF) was added for inhibition of proteases, the lysate was centrifuged at $6500 \mathrm{~g}$ for $20 \mathrm{~min}$ and kept at $-70^{\circ} \mathrm{C}$ until analysis. Tissue contents of bFGF, VEGF, PDGF and HGF were measured by enzyme-linked immunosorbent assay (ELISA) (R\&D system, Minneapolis, MN, USA). Each sample was assayed by duplicate and reported as means \pm s.d.

\section{Treatment of $\mathrm{C} 6$ cells in culture}

We separated C6 glioma cells in four groups: control cells (without treatment); cultures treated with Ang II $\left(10^{-7} \mathrm{M}\right)$; cultures treated with Losartan $\left(10^{-5} \mathrm{M}\right)$ (Stroth et al, 2000) and cultures treated with both Ang II and Losartan $(\mathrm{L}-\mathrm{A})$ at the same doses. All cultures were kept in a serum-free medium at $37^{\circ} \mathrm{C}$, in humidified environment with $5 \% \mathrm{CO}_{2}$. The culture medium used for cells incubated for long periods was changed every $24 \mathrm{~h}$ containing either Ang II, losartan or Ang ll plus losartan at the mentioned doses.

\section{Cell viability of $\mathrm{C} 6$ glioma in culture}

For quantification of cell viability, $6.5 \times 10^{5}$ glioma cells were cultured in microtitre plates (96 wells) with $100 \mu$ l culture medium and incubated for $24 \mathrm{~h}$ in a humidified atmosphere; $10 \mu \mathrm{l}$ of tetrazolium salts (MTT) was added to each well and left for $4 \mathrm{~h}$; these salts were cleaved into a coloured formazan product by metabolically active cells; afterwards $100 \mu \mathrm{l}$ of solubilisation solution was added, the plates were allowed to stand overnight inside the incubator. After checking for complete solubilisation of the purple formazan crystals, the absorbance was measured at $570 \mathrm{~nm}$, the reference wavelength was $650 \mathrm{~nm}$. We obtained the percentage of viable cells from three assays, the control was used as reference $(100 \%)$. Two replicates were perfomed using the same dosages.

\section{Apoptotic rate in vitro by flow cytometry}

For quantification of apoptosis by flow cytometry, $10^{6} \mathrm{C}^{6}$ glioma cells were trypsinised and transferred to $1.5 \mathrm{ml}$ Eppendorf tubes and cultured with DME culture medium either alone (controls) or with Losartan $10^{-5} \mathrm{M}$, or with Ang II $10^{-7} \mathrm{M}$, or with the mixture of losartan/Ang II (LA). Cultured cells were maintained at $37^{\circ} \mathrm{C}$ with $5 \% \mathrm{CO}_{2}$ during $6,12,24,48$ or $96 \mathrm{~h}$. The culture medium of those experimental groups which needed a long time of incubation was changed every day. At the end of the incubation period, the cells were centrifuged at $2000 \mathrm{~g}$, the supernatant was discarded. Induced apoptosis was detected by flow-cytometric analysis of the permeabilised, propidium-iodide-stained cells (Telford et al, 1992). Samples $\left(10^{6}\right.$ cells $\left.\mathrm{ml}^{-1}\right)$ were washed once in PBS and the pellets were re-suspended in $80 \%$ ethanol at $4^{\circ} \mathrm{C}$ for $60 \mathrm{~min}$. To detect apoptosis by flow cytometry, fixed cells were centrifuged, re-suspended in $1 \mathrm{ml} \mathrm{PBS}$, and kept at $37^{\circ} \mathrm{C}$ for $20 \mathrm{~min}$ before staining with a solution of $0.1 \%$ Triton X-100, $0.1 \mathrm{~mm} \mathrm{EDTA}(\mathrm{Na})_{2}$, $5 \mathrm{U} \mathrm{ml}^{-1} \mathrm{RNase}$ and $20 \mathrm{mg} \mathrm{ml}^{-1}$ propidium iodide in PBS. Samples were stored in the dark at room temperature and analysed with a Facscalibur Registered Trademark (Becton Dickinson \& Co., San Jose, CA, USA). Using the cell quest software (San Jose CA, USA), cell number $\left(10^{4}\right)$ was detected. Cell percentages in the different phases of the cell cycle were estimated according to the Fox's method (Lacombe et al, 1988). The assays were made by triplicate.

\section{Apoptotic rate in vitro by ELISA}

For quantification of apoptosis by ELISA, $10^{5} \mathrm{C}^{6}$ glioma cells were trypsinised and transferred to $1.5 \mathrm{ml}$ Eppendorf tubes and cultured with DME culture medium either alone (controls) or with Losartan 
$10^{-5} \mathrm{M}$, or with Ang II $10^{-7} \mathrm{M}$, or with the mixture of LA. Cultured cells were maintained at $37^{\circ} \mathrm{C}$ with $5 \% \mathrm{CO}_{2}$ during $6,12,24,48$ or $96 \mathrm{~h}$. The culture medium of those experimental groups which needed a long time of incubation was changed every day. At the end of the incubation period, the cells were centrifuged at $2000 \mathrm{~g}$, the supernatant was discarded and the cells were re-suspended in $1 \mathrm{ml}$ of culture medium with $10 \%$ DMSO and kept in liquid nitrogen until processed. At that time, the vials were warmed at $37^{\circ} \mathrm{C}$ and the cells were washed with culture medium by centrifugation at $2000 \mathrm{~g}$. The cells were then resuspended with incubation buffer (Cell Death detection ELISA Kit, Boehringer Mannheim catalogue: 1544675) at $4^{\circ} \mathrm{C}$ during $30 \mathrm{~min}$. The cellular lysate was centrifuged at $20000 \mathrm{~g}$ for $10 \mathrm{~min}$ and $400 \mu \mathrm{l}$ of the supernatant were removed (cytoplasmic fraction) and diluted 1:10 with incubation buffer, absorbance was measured at $405 \mathrm{~nm}$, the substrate solution was used as blank. The assays were made by triplicate; $10^{6}$ C6 cells in hypertonic buffer and $10^{6} \mathrm{C} 6$ cells with camptotensin were used as positive controls.

\section{Statistical analysis}

Values were expressed as means \pm s.d.; for the quantification of apoptotic rate, the kappa value was used as the interobserver variability value. Statistical analysis was made using SPSS v10 software. Comparisons between groups were made by ANOVA and Tukey tests. Statistical significance was set at a $P$-value of 0.05 .

\section{RESULTS}

Effect of the blockage of $\mathrm{AT}_{1}$ receptor on tumoral growth and apoptotic rate in vivo

All animals survived until the end of the experiment. In all controls, the tumour grew to a very large size (over $6 \mathrm{~cm}$ diameter); there was no case of spontaneous involution. When compared to controls (mean volume: $55 \pm 10 \mathrm{~cm}^{3}$ ) a significant decrease in tumour volume was seen in animals treated with $\mathrm{L} 40\left(30 \pm 7 \mathrm{~cm}^{3}\right)$ and with $\mathrm{L} 80\left(19 \pm 9 \mathrm{~cm}^{3}\right)(P<0.05$ and 0.01 , respectively). Results were similar to those from our previous report (Rivera et al, 2001). The apoptotic rate was higher in the L80 group $(84.2 \pm 4.1)$ than in controls $(23 \pm 8)$ or in the L40 group $(13.6 \pm 4.3)(P<0.01)$; no differences were seen when L40 group was compared with controls (Figure 1). Comparisons of haematological and chemical blood parameters measured at the end of the study showed no differences between groups.

\section{Growth factors in neoplastic tissue}

Mean contents of PDGF, bFGF and VEGF were higher in tumours from control animals $(\mathrm{PDGF}=1,195 \pm 261, \mathrm{bFGF}=893 \pm 4$, and VEGF $=154 \pm 7 \mathrm{pg} \mathrm{mg}^{-1}$ of tissue) than in tumours of animals treated with $\mathrm{L} 40 \quad(\mathrm{PDGF}=609 \pm 84, P=0.05 ; \quad b F G F=857 \pm 12$,

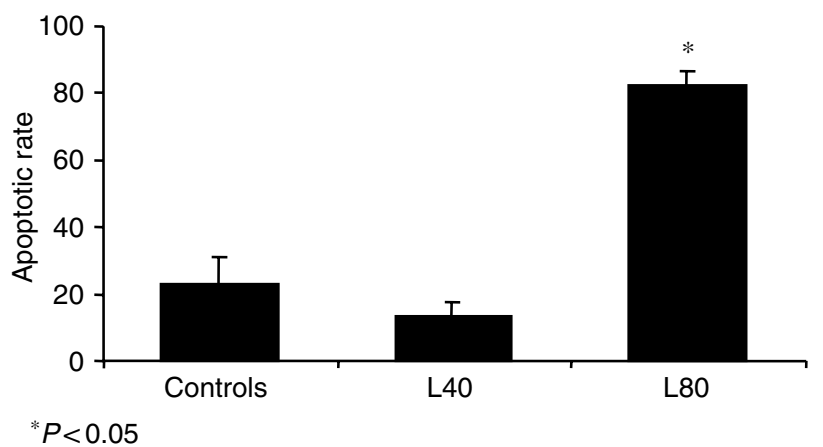

Figure I Effect of losartan administration at doses of 40 and $80 \mathrm{mg} \mathrm{Kg}^{-1}$ on the apoptotic rate in tissue sections of C6 glioma (TUNEL stain). A significant increase of the apoptosis was observed with losartan treatment at $80 \mathrm{mg} \mathrm{Kg}^{-1}$.
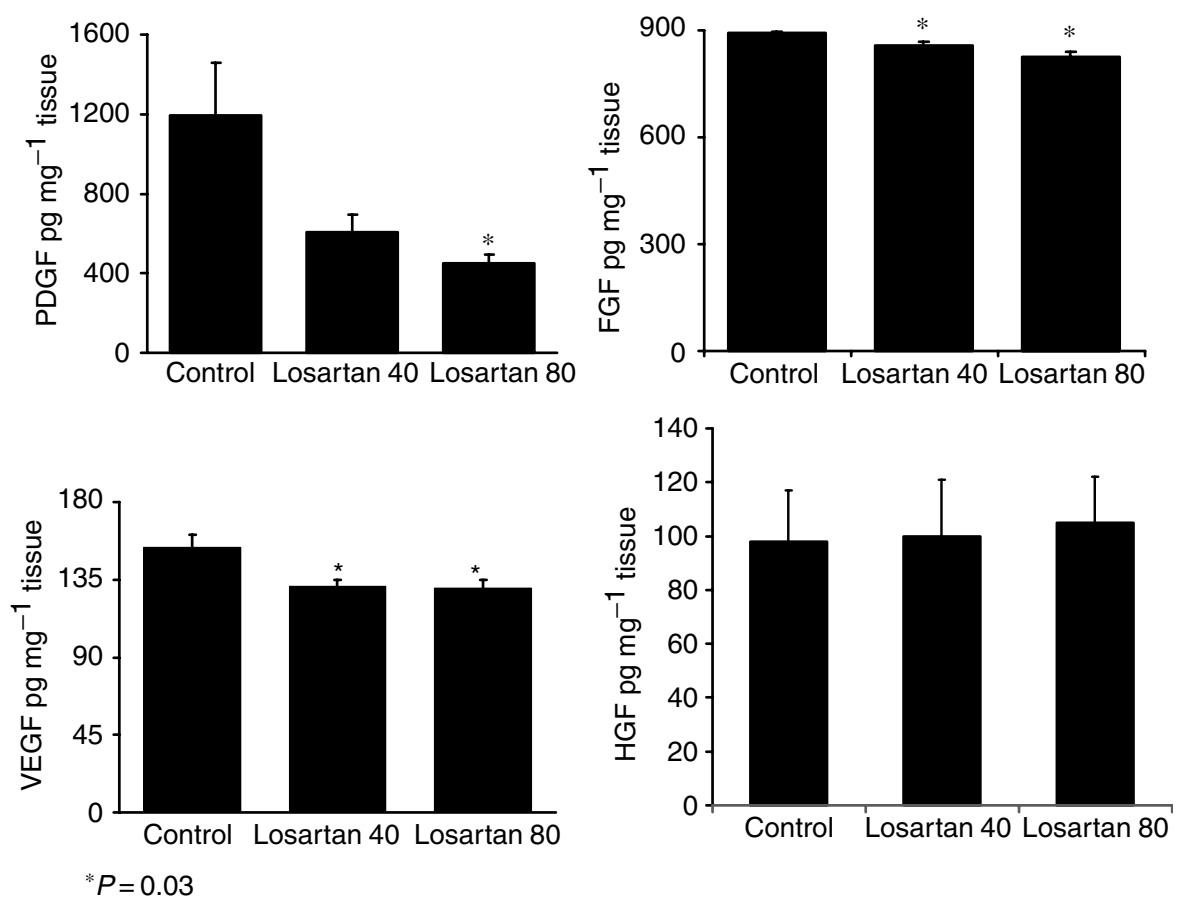

Figure 2 Effect of the blockage of AT, receptor with losartan on the contents of PDGF, FGF, VEGF and HGF in C6 rat glioma. A significant reduction in the concentration of PDGF, FGF and VEGF was obtained with losartan treatment. 
$P=0.035 ;$ and $\left.\mathrm{VEGF}=131 \pm 4 \mathrm{pg} \mathrm{mg}^{-1}, \quad P=0.011\right)$ and those treated with $\mathrm{L} 80(\mathrm{PDGF}=451 \pm 45, P=0.018 ; \quad b F G F=827 \pm 14$, $P=0.001$; and $\mathrm{VEGF}=105 \pm 19 \mathrm{pg} \mathrm{mg}^{-1}, P=0.013$ ). However, no significant differences were seen on HGF contents between controls $\left(97 \pm 20 \mathrm{pg} \mathrm{mg}^{-1}\right)$ and $\mathrm{L} 40-\left(100 \pm 29 \mathrm{pg} \mathrm{mg}^{-1}\right)$ or L80treated rats $\left(105 \pm 19 \mathrm{pg} \mathrm{mg}^{-1}\right)(P=0.65)$ (Figure 2).

\section{Effects of Ang II, losartan and LA on cell cultures}

The percentage of viable cells was significantly smaller in cultures treated with $\mathrm{L}-\mathrm{A}$ at 6 and $12 \mathrm{~h}$ as compared with controls $(P=0.01$ and 0.05 , respectively); however, no differences were seen later, at 24,48 and $96 \mathrm{~h}$. The percentage of viable cells was higher in cells cultured with Ang II at 48 and $96 \mathrm{~h}$ as compared to controls ( $P=0.04$ for both determinations). Treatment with Losartan had no effect on cell viability (Figure 3 ).

\section{Apoptosis rate in vitro by flow cytometry}

A significative increase of apoptosis was observed in cells treated with $\mathrm{L}-\mathrm{A}$ particularly at $6 \mathrm{~h}$ as compared to controls $(P=0.05)$ and with the losartan group $(P=0.012)$, and at $12 \mathrm{~h}$ as compared with the groups Ang II $(P=0.007)$ and losartan $(P=0.001)$, which was maintained at $24 \mathrm{~h}$ with losartan $(P=0.007)$. No differences were found at 48,72 and $96 \mathrm{~h}$ (Figure $4 \mathrm{~A}$ ).

\section{Apoptosis rate in vitro by ELISA}

Cells cultured with Ang II showed increased apoptotic rate at $6 \mathrm{~h}$ when compared with losartan $(P=0.012)$ and at $12 \mathrm{~h}$ when compared to controls $(P=0.012)$. When compared with controls, apoptosis was increased in cells treated with $\mathrm{L}-\mathrm{A}(P=0.007)$, with losartan $(P=0.003)$ and with Ang II $(P=0.011)$ at $6 \mathrm{~h}$, as well as the cells treated with $\mathrm{L}-\mathrm{A}$ at $12 \mathrm{~h}(P=0.05)$. No differences were found at 24, 48, 72 and $96 \mathrm{~h}$ (Figure $4 \mathrm{~B}$ ).

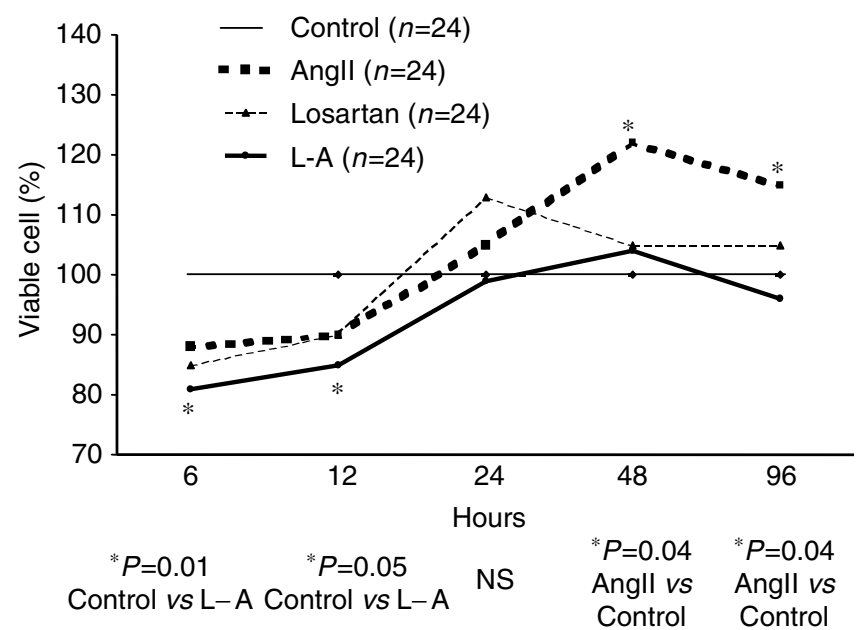

Figure 3 Effects of the administration of Ang $\|\left(10^{-7} \mathrm{M}\right)$, losartan $\left(10^{-5} \mathrm{M}\right)$, or Ang II plus losartan on cultured $\mathrm{C} 6$ cells. During the initial $12 \mathrm{~h}$ of treatment, there was a significant reduction of viability in the cells treated with Ang II plus losartan; in contrast, after $48 \mathrm{~h}$, a significant increase of viability was observed in the cells treated with Ang II alone.
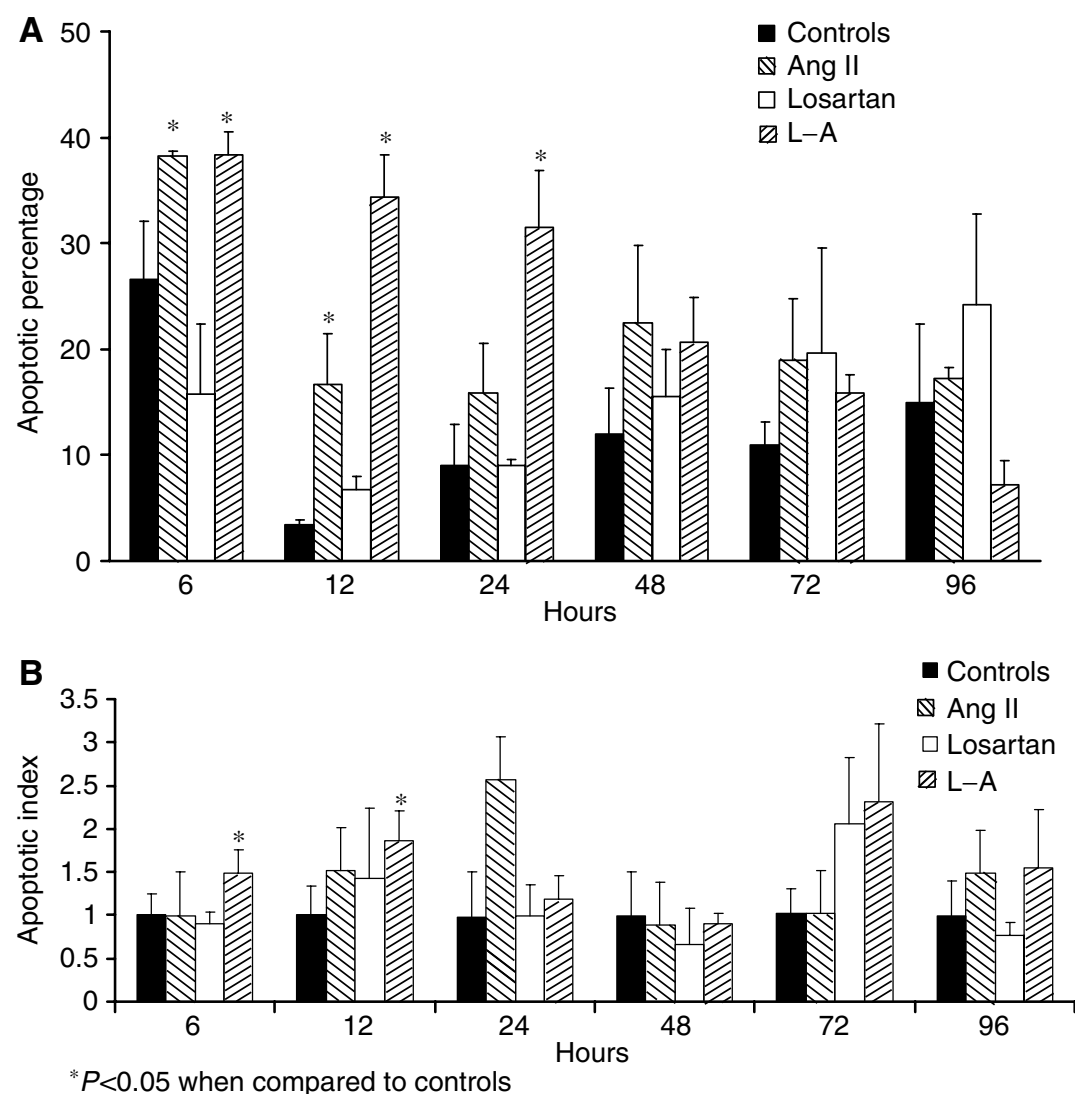

Figure 4 Effects of Ang II $\left(10^{-7} \mathrm{M}\right)$, losartan $\left(10^{-5} \mathrm{M}\right)$ and Ang II plus losartan on apoptosis in cultured glioma C6 cells measured either by flow cytometry (A) or by ELISA (B). In both determinations the cells treated with losartan plus Ang II showed an increase of apoptosis during the initial hours after treatment. 


\section{DISCUSSION}

Malignant gliomas contain large quantities of VEGF, PDGF, bFGF and HGF, as well as their receptors (Stefanik et al, 1991; Westermark et al, 1995; Arrieta et al, 2002; Steiner et al, 2003); their concentrations are related to vascular density, radioresistance, cell proliferation, degree of malignancy and patients survival (Westermark et al, 1995; Gorski et al, 1999). Angiotensin II stimulates the production of these growth factors (Peng et al, 2001; Tamarat et al, 2002); this effect can be blocked by $\mathrm{AT}_{1}$ antagonists but not by $\mathrm{AT}_{2}$ antagonists (Tamarat et al, 2002). Normal and neoplasic astrocytes including $\mathrm{C} 6$ glioma cells express $\mathrm{AT}_{1}$ and $\mathrm{AT}_{2}$ receptors for Ang II (Rivera et al, 2001; Fogarty et al, 2002). We have previously shown in experimentally induced C6 glioma in rats that the selective blockage of $\mathrm{AT}_{1}$ receptor reduces cell proliferation, angiogenesis and tumour growth (Rivera et al, 2001). However, the participative mechanisms were unclear. In this study, we found that the blockage of $\mathrm{AT}_{1}$ decreases the synthesis of the growth factors VEGF, PDGF and bFGF, coincident with the reduction of tumour size, cell proliferation and vascular density. The effect of losartan in the synthesis of growth factors is more intense in PDGF, which is inhibited with the blockage of AT1 in several experimental models; nonetheless, VEGF and FGF syntheses are also statistically reduced. However, the reduction of angiogenesis previously reported might be a consequence of VEGF and FGF inhibition due to a blockage of PDGF's stimuli, this would explain why the effect is not dose-dependent on losartan. Although HGF is also overexpressed in malignant gliomas and related to the degree of malignancy (Arrieta et al, 2002) and Ang II also participates in its synthesis (Matsumoto et al, 2003), in this study no effect on HGF contents was observed after blockage of the $\mathrm{AT}_{1}$ receptor.

Additionally, our results in vitro show that the reduction on cell viability within the firsth of Ang II plus losartan administration was also associated with the induction of apoptosis but only during the first $12 \mathrm{~h}$, whereas the administration of Ang II alone stimulates cell proliferation during $24 \mathrm{~h}$ after exposure. Increase of apoptosis in glioma C6 in vivo was seen only at high doses of losartan $\left(80 \mathrm{mg} \mathrm{Kg}^{-1}\right)$; this effect was also obtained in cultured C6 cells with the simultaneous administration of losartan and Ang II; it seems that the selective blockage of $\mathrm{AT}_{1}$ may lead to disequilibrium of $\mathrm{AT}_{1} / \mathrm{AT}_{2}$ relation that promotes $\mathrm{AT}_{2}$ receptor stimulation which, in turn, could increase its proapoptotic effects. It is also likely that, in this condition, the presence of Ang II promotes apoptosis, as this effect is prevented by deletion of the $\mathrm{AT}_{2}$ receptor gene (Yamada et al, 1996). Our findings are in agreement with studies in PC12W cells and neurons from newborn rats, showing that apoptosis is increased either by the selective stimulation of $\mathrm{AT}_{2}$ receptor or by the blockage of $\mathrm{AT}_{1}$ receptor simultaneous to the administration of Ang ll (Stoll et al, 1995; Yamada et al, 1996; Goldenberg et al, 2001; Suzuki et al, 2002).

Subucutaneous C6 glioma, in contrast to brain glioma, allowed us to measure tumour growth for a longer time and to determine a potential therapeutic effect when the drug is administered for long periods. However, similar results are to be expected in brain glioma as the blood-brain barrier is interrupted in brain tumours, facilitating the entrance of drugs into the tumour.

Angiogenesis and apoptosis are primordial features of malignant tumours, constituting attractive therapeutic targets; drugs that inhibit angiogenesis or promote apoptosis could be associated to cytotoxic agents to improve antitumoral therapy. The fact that multifunctional hormonal systems, such as the reninangiotensin-aldosterone system, influence tumour growth and angiogenesis provides interesting pathways to the study of cancer. The antineoplastic activity obtained by the selective blockage of $\mathrm{AT}_{1}$ in malignant glioma seems to be mediated by two different mechanisms, inhibition of the synthesis of growth factors and promotion of apoptosis, providing a potential therapeutic adjuvant for malignant gliomas.

\section{ACKNOWLEDGEMENTS}

This work was partially supported by fellowships to Oscar Arrieta, Elizabeth Escobar, Roberto García-Navarrete and Benjamín Pineda from the ARMSTRONG Foundation.

\section{REFERENCES}

Andrade SP, Cardoso CC, Machado RD, Beraldo WT (1996) Angiotensin-II induced angiogenesis in sponge implants in mice. Int J Microcirc Clin Exp 16: $302-307$

Ariza A, Fernandez LA, Inagami T, Kim JH, Manuelidis EE (1988) Renin in glioblastoma multiforme and its role in neovascularization. Am J Clin Pathol 90: $341-437$

Arrieta O, Garcia E, Guevara P, Garcia NR, Ondarza R, Rembao D, Sotelo J (2002) Hepatocyte growth factor is associated with poor prognosis of malignant gliomas and is a predictor for recurrence of meningioma. Cancer 94: $3210-3218$

Arrieta O, Guevara P, Reyes S, Ortiz A, Rembao D, Sotelo J (1998) Protamine inhibits angiogenesis and growth of C6 rat glioma; a synergistic effect when combined with carmustine. Eur J Cancer 34: $2102-2106$

Arrieta O, Guevara P, Reyes S, Palencia G, Rivera E, Sotelo J (2001) Paradoxical effect of aspirin on the growth of C6 rat glioma and on time of development of ENU-induced tumors of the nervous system. J Cancer Res Clin Oncol 127: 681-686

Berry MG, Goode AW, Puddefoot JR, Vinson GP, Carpenter R (2000) Integrin $\beta 1$ upregulation in MCF-7 breast cancer cells by angiotensin II. Eur J Surg Oncol 26: 25-29

Brink M, Chrast J, Price SR, Mitch WE, Delafontaine P (1999) Angiotensin II stimulates gene expression of cardiac Insulin-like growth factor I and its receptor through effects on blood pressure and food intake. Hypertension 34: $1053-1059$

Coker ML, Jolly JR, Joffs C, Etoh T, Holder JR, Bond BR, Spinale FG (2001) Matrix metalloproteinase expression and activity in isolated myocytes after neurohormonal stimulation. Am J Physiol Heart Circ Physiol 281: H543 - H551

Cook JL, Giardina JF, Zhang Z, Re RN (2002) Intracellular ANG II increases the long isoform of PDGF mRNA in rat hepatoma cells. J Mol Cell Cardiol 34: $1525-1537$

Egami K, Murohara T, Shimada T, Sasaki K, Shintani S, Sugaya T, Ishii M, Akagi T, Ikeda H, Matsuishi T, Imaizumi T (2003) Role of host angiotensin II type 1 receptor in tumor angiogenesis and growth. J Clin Invest 112: $67-75$

Escobar E, Rodríguez-Reyna T, Arrieta O, Sotelo J (2004) Angiotensin II, cell proliferation and angiogenesis regulator: Biologic and therapeutic implications in cancer. Curr Vasc Pharmacol 2: $385-399$

Fernandez LA, Twickler J, Mead A (1985) Neovascularization produced by angiotensin II. J Lab Clin Med 105: 141 - 145

Fogarty DJ, Sánchez GV, Matute C (2002) Multiple angiotensin receptor subtypes in normal and tumor astrocytes in vitro. Glia 39: 304-313

Fujimoto Y, Sasaki T, Tsuchida A, Chayama K (2001) ANG II type 1 receptor expression in human pancreatic cancer and growth inhibition by ANG II type 1 receptor antagonist. FEBS Lett 495: 197-200

Fujita M, Hayashi I, Yamashina S, Itoman M, Majima M (2002) Blockade of angiotensin AT1a receptor signaling reduces tumor growth, angiogenesis, and metastasis. Biochem Biophys Res Commun 294: $441-447$

Fujiyama S, Matsubara H, Nozawa Y, Maruyama K, Mori Y, Tsutsumi Y, Masaki H, Uchiyama Y, Koyama Y, Nose A, Iba O, Tateishi E, Ogata N, Jyo N, Higashiyama S, Iwasaka T (2001) Angiotensin AT(1) and AT(2) receptors differentially regulate angiopoietin-2 and vascular endothelial growth factor expression and angiogenesis by modulating heparin 
binding-epidermal growth factor (EGF)-mediated EGF receptor transactivation. Circ Res 88: $22-29$

Ganong WF (1984) The brain renin-angiotensin system. Ann Rev Physiol 46: $17-31$

Goldenberg I, Grossman E, Jacobson KA, Shneyvays V, Shainberg A (2001) Angiotensin II-induced apoptosis in rat cardiomyocyte culture: a possible role of AT1 and AT2 receptors. J Hypertens 19: 1681-1689

Gorski DH, Beckett MA, Jaskowiak NT, Calvin DP, Mauceri HJ, Salloum RM, Seetharam S, Koons A, Hari DM, Kufe DW, Weichselbaum RR (1999) Blockage of the vascular endothelial growth factor stress response increases the antitumor effects of ionizing radiation. Cancer Res 59: $3374-3378$

Guerra FK, Ciuffo GM, Elizalde PV, Charreau EH, Saavedra JM (1993) Enhanced expression of angiotensin II receptor subtypes and angiotensin converting enzyme in medroxy progesterone-induced mouse mammary adenocarcinomas. Biochem Biophys Res Commun 193: 93-99

Guevara P, Sotelo J (1999) C6 rat glioma grown into the peritoneal cavity, a large source of tumoral cells for subcutaneous transplant of glioma. J Neurooncol 44: 91 -92

Haddad GE, Blackwell K, Bikhazi A (2003) Regulation of insulin-like growth factor-1 by the renin-angiotensin system during regression of cardiac eccentric hypertrophy through angiotensin-converting enzyme inhibitor and AT1 antagonist. Can J Physiol Pharmacol 81: $142-149$

Hamaguchi A, Kim S, Izumi Y, Zhan Y, Yamanaka S, Iwao H (1999) Contribution of extracellular signal-regulated kinase to angiotensin IIinduced transforming growth factor-beta 1 expression in vascular smooth muscle cells. Hypertension 34: 126-131

Hii SI, Nicol DL, Gotley DC, Thompson LC, Green MK, Jonsson JR (1998) Captopril inhibits tumour growth in a xenograft model of human renal cell carcinoma. $\mathrm{Br} J$ Cancer 77: $880-883$

Inwang ER, Puddefoot JR, Brown CL, Goode AW, Marsigliante S, Ho MM, Payne JG, Vinson GP (1997) Angiotensin II type 1 receptor expression in human breast tissues. Br J Cancer 75: 1279-1283

Juillerat-Jeanneret L, Celerier J, Chapuis Bernasconi C, Nguyen G, Wostl W, Maerki HP, Janzer RC, Corvol P, Gasc JM (2004) Renin and angiotensinogen expression and functions in growth and apoptosis of human glioblastoma. Br J Cancer 90: 1059-1068

Kagami S, Border WA, Miller DE, Noble NA (1994) Angiotensin II stimulates extracellular matrix protein synthesis through induction of transforming growth factor-beta expression in rat glomerular mesangial cells. J Clin Invest 93: 2431-2437

Khachigian LM, Takuwa Y, Collins T (2000) Mechanisms of angiotensin IIinduced platelet-derived growth factor gene expression. Mol Cell Biochem 212: $183-186$

Lacombe F, Belloc F, Bernard P, Boisseau MR (1988) Evaluation of four methods of DNA distribution data analysis based on bromodeoxyuridine/DNA bivariate data. Cytometry 9: 245-253

Le Noble FA, Hekking JW, Van Straaten HW, Slaaf DW, Struyker-Boudier HA (1991) Angiotensin II stimulates angiogenesis in the chorioallantoic membrane of the chick embryo. Eur J Pharmacol 195: 305-306

Lopez-Gonzalez MA, Sotelo J (2000) Brain tumors in mexico: characteristics and prognosis of glioblastoma. Surg Neurol 53: 157-162

Matsumoto K, Morishita R, Tomita N, Moriguchi A, Komai N, Aoki M, Matsumoto K, Nakamura T, Higaki J, Ogihara T (2003) Improvement of endothelial dysfunction by angiotensin II blockade accompanied by induction of vascular hepatocyte growth factor system in diabetic spontaneously hypertensive rats. Heart Vessels 18: 18-25

Miyajima A, Kosaka T, Asano T, Seta K, Kawai T, Hayakawa M (2002) ANG II type I antagonist prevents pulmonary metastasis of murine renal cancer by inhibiting tumor angiogenesis. Cancer Res 62: 4176-4179

Moriyama T, Kataoka H, Koono M, Wakaisaka S (1999) Expression of hepatocyte growth factor/scatter factor and its receptor c-MET in brain tumors: evidence for a role in progression of astrocytic tumors. Int J Mol Med 3: $531-536$

Muscella A, Greco S, Elia MG, Storelli C, Marsigliante S (2002) Angiotensin II stimulation of $\mathrm{Na}+/ \mathrm{K}+\mathrm{ATPase}$ activity and cell growth by calciumindependent pathway in MCF-7 breast cancer cells. J Endocrinol 173: $315-323$
Ohta K, Kim S, Hamaguchi A, Yukimara T, Miura K, Takaori K, Iwao H (1994) Role of angiotensin II in extracelluar matrix and transforming growth factor-beta 1 expression in hypertensive rats. Eur J Pharmacol 269: $115-119$

Otani A, Takagi H, Oh H, Koyama S, Honda Y (2001) Angiotensin II induces expression of the Tie2 receptor ligand, angiopoietin 2, in bovine retinal endothelial cells. Diabetes 50: $867-875$

Otani A, Takagi H, Suzuma K, Honda Y (1998) Angiotensin II potentiates vascular endothelial growth factor-induced angiogenic activity in retinal microcapillary endothelial cells. Circ Res 82: 619-628

Peng H, Moffett J, Myers J, Fang X, Stachowiak EK, Maher P, Kratz E, Hines J, Fluharty SJ, Mizukoshi E, Bloom DC, Stachowiak MK (2001) Novel nuclear signaling pathway mediates activation of fibroblast growth factor-2 gene by type 1 and type 2 angiotensin II receptors. Mol Biol Cell 12: $449-462$

Rivera E, Arrieta O, Guevara P, Duarte-Rojo A, Sotelo J (2001) AT1 receptor is present in glioma cells; its blockage reduces the growth of rat glioma. Br J Cancer 85: $1396-1399$

Schmidt NO, Westphal M, Hagel C, Ergun S, Stavrou D, Rosen EM, Lamszus K (1999) Levels of vascular endothelial growth factor hepatocyte growth factor/scatter factor and basic fibroblast growth factor in human gliomas and their relation to angiogenesis. Int $J$ Cancer 84: $10-18$

Stefanik DF, Rizkalla LR, Soi A, Goldblatt SA, Rizkalla WM (1991) Acidic and basic fibroblast growth factors are present in glioblastoma multiforme. Cancer Res 51: 5760 - 5765

Steiner HH, Karcher S, Mueller MM, Nalbantis E, Kunze S, Herold-Mende C (2003) Autocrine pathways of the vascular endothelial growth factor (VEGF) in glioblastoma multiforme: clinical relevance of radiationinduced increase of VEGF levels. I Neurooncol 66: 129-138

Stoll M, Steckelings UM, Paul M, Bottarri SP, Metzger R, Unger T (1995) The angiotensin AT2-receptor mediates inhibition of cell proliferation in coronary endothelial cells. J Clin Invest 95: 651-657

Stroth U, Blume A, Mielke K, Unger T (2000) Angiotensin AT(2) receptor stimulates ERK1 and ERK2 in quiescent but inhibits ERK in NGFstimulated PC12 cells. Brain Res Mol Brain Res 78: 175-180

Strugar JG, Criscuolo GR, Rothbart D, Harrington WN (1995) Vascular endothelial growth/permeability factor expression in human glioma specimens: correlation with vasogenic brain edema and tumor-associated cysts. J Neurosurg 83: 682-689

Suzuki J, Iwai M, Nakagami $\mathrm{H}$, Wu L, Chen R, Sugaya T, Hamada M, Hiwada K, Horiuchi M (2002) Role of angiotensin II - regulates apoptosis through distinct AT1 and AT2 receptors in neointimal formation. Circulation 106: 847-853

Takeda H, Kondo S (2001) Differences between squamous cell carcinoma and keratoacanthoma in angiotensin type-1 receptor expression. Am J Pathol 158: $1633-1637$

Tamarat R, Silvestre JS, Durie M, Levy BI (2002) Angiotensin II angiogenic efect in vivo involves vascular endothelial growth factor- and inflammation-related pathways. Lab Invest 82: 747-756

Telford WG, King LE, Fraker PJ (1992) Comparative evaluation of several DNA binding dyes in the detection of apoptosis-associated chromatin degradation by flow cytometry. Cytometry 13: 137-143

Volpert OV, Ward WF, Lingen MW, Chesler L, Solt DB, Johnson MD, Molteni A, Polverini PJ, Bouck NP (1996) Captopril inhibits angiogenesis and slows the growth of experimental tumors in rats. J Clin Invest 98: $671-679$

Weigert C, Brodbeck K, Klopfer K, Haring U, Schleicher ED (2002) Angiotensin II induces human TGF-beta 1 promoter activation: similarity to hyperglycaemia. Diabetologia 45: $890-898$

Westermark B, Heldin CH, Nister M (1995) Platelet-derived growth factor in human glioma. Glia 15: 257-563

Yamada T, Horiuchi M, Dzau VJ (1996) Angiotensin II type 2 receptor mediates programmed cell death. Proc Natl Acad Sci USA 93: 156-160

Yoshiji H, Yoshii J, Ikenaka Y, Noguchi R, Yanase K, Tsujinoue H, Imazu $\mathrm{H}$, Fukui $\mathrm{H}$ (2002) Suppression of the renin-angiotensin system attenuates vascular endothelial growth factor-mediated tumor development and angiogenesis in murine hepatocellular carcinoma cells. Int $J$ Oncol 20: $1227-1231$ 